\title{
Pemetaan Curah Hujan Dalam Upaya Mengurangi Resiko Bencana Hidrometeorologi Dengan Sistem Informasi Geografis (SIG) Untuk Wilayah Kalimantan Utara
}

\author{
Rachel Zandra Singal ${ }^{* 1}$, Noptri Jumario ${ }^{2}$ \\ ${ }^{1}$ Program Studi Teknik Sipil, FT Universitas Kaltara, Tanjung Selor \\ ${ }^{2}$ Forum DAS Kalimantan Utara, Tanjung Selor \\ E-mail: ${ }^{1}$ rachelzandrasingal2017@gmail.com, ${ }^{2}$ jumario20@gmail.com
}

Received 17 September 2019; Reviewed 04 Oktober 2019; Accepted 26 November 2019

Journal Homepage: http://jurnal.borneo.ac.id/index.php/borneoengineering

\begin{abstract}
North Kalimantan is one of the regions in Indonesia which is prone to hydrometeorological disasters. The purpose of this study was to determine the rainfall analysis of the North Kalimantan Region as a basis in finding rainfall levels in areas that do not have climatological stations, knowing the rainfall maps of the North Kalimantan Region and knowing the conditions of high rainfall causing flood prone in the North Kalimantan region. Rainfall data collection locations are climatology stations Tanjung Harapan, Juwata, Tuvai Semaring, Kalimarau and R.A. Bessing. Rainfall data is taken from OGIMET for 10 years. The result of rainfall analysis is the average monthly rainfall, which is from January to December. The method used to determine the monthly rainfall value in the North Kalimantan region is the Spatial Analyst Interpolation Kriging method. The results are in the form of monthly rainfall maps, from January to December. Monthly rainfall map is a source of information on the value of rainfall in the region in North Kalimantan. Maximum rainfall is found in the areas of Tanjung Selor and Tarakan, namely January 313,368 mm, May 366,238 mm, July 358,868 mm and December 324,513 mm. Map of monthly rainfall in January, May, July and December is a parameter to see the condition of high rainfall causing hydrometeorological disasters. Through this research it is expected to anticipate the risk of disasters caused by the weather.
\end{abstract}

Keywords: North Kalimantan Region; Rainfall Mapping; Hydrometeorological Disasters; Geographic Information System; Kriging Method

\begin{abstract}
Abstrak
Kalimantan Utara merupakan salah satu wilayah di Indonesia yang rawan terjadi bencana hidrometeorologi. Tujuan penelitian adalah untuk mengetahui analisa curah hujan Wilayah Kalimantan Utara sebagai dasar dalam mencari tingkat curah hujan pada daerah yang tidak memiliki stasiun klimatologi, mengetahui peta curah hujan Wilayah Kalimantan Utara dan mengetahui kondisi curah hujan tinggi menyebabkan rawan banjir di wilayah Kalimantan Utara. Lokasi pengambilan data curah hujan adalah stasiun klimatologi Tanjung Harapan, Juwata, Tuvai Semaring, Kalimarau dan R.A. Bessing. Data curah hujan diambil dari OGIMET periode 10 tahun. Hasil analisa curah hujan adalah rata-rata curah hujan bulanan, yaitu bulan Januari hingga Desember. Metode yang digunakan untuk mengetahui nilai curah hujan bulanan wilayah Kalimantan Utara adalah metode Spatial Analyst Interpolation - Kriging. Hasil berupa peta curah hujan bulanan, yaitu bulan Januari hingga Desember. Peta curah hujan bulanan menjadi sumber informasi nilai curah hujan di wilayah di Kalimantan Utara. Curah hujan maksimum terdapat di wilayah Tanjung Selor dan Tarakan yaitu Januari 313,368 mm, Mei 366,238 mm, Juli 358,868 mm dan Desember 324,513 mm. Peta curah hujan bulanan bulan Januari, Mei, Juli dan Desember menjadi parameter untuk melihat kondisi curah hujan tinggi penyebab bencana hidrometeorologi. Melalui penelitian ini diharapkan dapat mengantisipasi resiko bencana yang disebabkan oleh cuaca.
\end{abstract}

Kata Kunci: Wilayah Kalimantan Utara; Pemetaan Curah Hujan; Bencana Hidrometeorologi; Sistem Informasi Geografis; Metode Kriging 


\section{Pendahuluan}

Bencana Hidrometeorologi merupakan bencana yang disebabkan oleh iklim atau cuaca seperti curah hujan, kelembaban, temperature dan angin yang disebut sebagai parameter-parameter meteorology (H. Suryatmojo, 2017). Banjir yang terjadi beberapa tahun belakangan ini tepatnya pada tahun 2015 menjadi bencana hidrometeorologi yang besar di Kalimantan Utara secara khusus wilayah Kabupaten Bulungan. Intensitas curah hujan yang sangat tinggi dalam beberapa hari menjadi salah satu penyebab terjadinya banjir di wilayah Kabupaten Bulungan. Hampir seluruh wilayah Kabupaten Bulungan mengalami intensitas curah hujan yang tinggi, baik itu pada daerah hulu maupun hilir Sungai Kayan. Sehingga aliran air sungai tidak dapat menampung debit air dan meluap hingga ke daratan, banjir menutupi sebagian besar daratan wilayah Kabupaten Bulungan. Sungai Kayan merupakan sungai yang mengalir di Kalimantan Utara, tepatnya melintas di wilayah Kabupaten Bulungan dan Kabupaten Malinau. Daerah Aliran Sungai (DAS) Kayan sangat luas, yaitu daerah hulu di wilayah Desa Long Apung, Kabupaten Malinau sedangkan daerah hilir di wilayah Kecamatan Tanjung Palas Tengah, Kabupaten Bulungan. Dapat di rasakan dampak dari bencana banjir yang terjadi bagi seluruh aktivitas masyarakat di berbagai aspek. Pertanian, perkantoran, perdagangan, transportasi bahkan sosial ekonomi masyarakat menjadi terganggu.

Upaya mengurangi dampak bencana hidrometeorologi, salah satunya adalah dengan cara melakukan pemetaan terhadap tingkat curah hujan bulanan di wilayah Kabupaten Bulungan. Dengan mengetahui tingkat curah hujan melalui pemetaan curah hujan, maka dapat di lakukan antisipasi terhadap segala bencana yang mungkin saja terjadi. Trend bencana hidrometeorologi meningkat belakangan ini, dikarenakan intensitas curah hujan yang begitu ekstrim (S. Adi, 2013). Sehingga berbagai upaya harus dilakukan untuk mengurangi dampak akibat bencana hidrometeorologi tersebut. Pemetaan curah hujan diperlukan sebagai sumber informasi curah hujan di Kalimantan Utara secara visual, yang pada gilirannya bisa dijadikan sebagai landasan kebijakan terkait mitigasi bencana di wilayah Kalimantan Utara. Salah satu langkah untuk meminimalkan kerugian akibat bencana hidrometeorologi adalah dengan mengetahui pola keterpaparan banjir di wilayah yang rentan banjir, dan curah hujan pemicu kejadian banjir terutama berasal dari 3 hari berturut-turut sebelum kejadian banjir (M. Gusti Hardi, dkk, 2017). Sejalan dengan penelitian tersebut, penting untuk diketahui informasi secara visual agar diketahui wilayah mana yang memiliki tingkat curah hujan tinggi, rentan terhadap bencana hidrometeorologi dan selanjutnya dijadikan landasan kebijakan mitigasi bencana.

\section{Metode Penelitian}

Pemetaan curah hujan dalam upaya mengurangi resiko bencana hidrometeorologi dengan Sistem Informasi Geografis (SIG) untuk wilayah Kalimantan Utara, menggunakan data curah hujan bulanan dengan lima titik stasiun meteorologi dan klimatologi wilayah Kalimantan Utara. Metode yang digunakan adalah dengan metode Spatial Analyst Interpolation - Kriging.

\subsection{Lokasi Penelitian}

Data curah hujan diambil pada beberapa wilayah di Kalimantan Utara dengan menggunakan data pengamatan BMKG pada stasiun klimatologi. Lokasi studi dalam pengumpulan data curah hujan adalah Stasiun Klimatologi yang tercatat memiliki kode dari WMO (World Meteorological Organization) Badan Meteorologi Klimatologi dan Geofisika, Pusat Klimatologi Penerbangan.

\subsection{Tahapan Pelaksanaan Penelitian}

Tahapan pelaksanaan penelitian dapat dijelaskan dalam uraian sebagai berikut:

1. Studi Literatur 
Tahap ini merupakan tahapan persiapan dalam memulai pelaksanaan penelitian. Pelaksanaannya adalah dengan mengumpulkan informasi terhadap penelitian-penelitian terdahulu dan literatur yang berkaitan dengan topik bahasan dan metode yang digunakan dalam penelitian (Sugiyono, 2015).

2. Pengumpulan Data

Tahapan pengumpulan data dengan menggunakan software Ogimet. Sehingga sangat penting untuk Stasiun Klimatologi memiliki kode WMO Badan Meteorologi Klimatologi dan Geofisika, Pusat Klimatologi Penerbangan. Data yang dikumpulkan adalah data Curah Hujan Harian dalam rentang waktu 10 tahun untuk beberapa wilayah di Kalimantan Utara. Selain itu diperlukan koordinat masing-masing stasiun klimatologi serta peta Wilayah Kalimantan Utara.

3. Analisa dan Hasil Analisa

Berikut ini merupakan tahapan yang dilakukan pada analisa dan pembahasan:

a. Analisa Curah Hujan.

Tahapan dalam Analisa curah hujan adalah dengan menghitung rata-rata curah hujan bulanan masing-masing wilayah.

b. Pemetaan tingkat curah hujan bulanan menggunakan Sistem Informasi Geografis (SIG).

Pemetaan dengan menggunakan Sistem Informasi Geografis (SIG) menurut Utara Praha, dkk (2001) sebagai alat yang dapat membantu dalam proses mengumpulkan, memeriksa, mengintegrasikan dan menganalisa informasi-informasi tentang data yang dikumpulkan. Dalam penelitian ini proses yang dilakukan adalah dengan interpolasi besaran dari curah hujan yang dihasilkan pada proses awal, untuk setiap titik stasiun klimatologi yang ada pada wilayah Kalimantan Utara.

c. Pembahasan pemetaan terhadap tingkat resiko bencana yang disebabkan oleh curah hujan.

Hasil akhir dari analisa data, baik itu menghitung besaran curah hujan dengan proses pemetaan dengan metode Sistem Informasi Geografis (SIG) adalah berupa peta kontur atau peta perwilayah untuk besaran curah hujan pada daerah di Kalimantan Utara.

\section{Hasil dan Pembahasan}

Hasil pemetaan curah hujan bulanan yaitu berupa peta curah hujan bulanan untuk wilayah Kalimantan Utara. Peta tersebut dapat memberikan informasi untuk besaran curah hujan bulanan pada daerah yang tidak memiliki stasiun meteorologi dan klimatologi. Proses dalam pemetaan curah hujan pada penelitian ini adalah menggunakan Spatial Analyst Tool dengan metode Interpolation - Kriging. Proses interpolasi tersebut dilakukan untuk mengetahui atau memprediksi nilai curah hujan pada suatu wilayah yang tidak memiliki stasiun meteorology dan klimatologi, berdasarkan nilai curah hujan dari titik-titik koordinat disekitarnya. Nilai curah hujan diantara data titik koordinat stasiun meteorologi, klimatologi dan geofisika menujukan korelasi spasial yang menujukan bobot dan digunakan dalam interpolasi. Diasumsikan bahwa setiap titik yang dihubungkan mempunyai sebuah persamaan yang digunakan untuk memprediksi wilayah yang tidak memiliki data atau informasi, dalam hal ini nilai atau besaran curah hujan.

Besaran curah hujan rata-rata pada beberapa wilaya di Kalimantan Utara dapat dilihat pada Gambar 2 berikut ini: 


\section{Grafik Perbandingan Nilai Rata-Rata Curah Hujan}

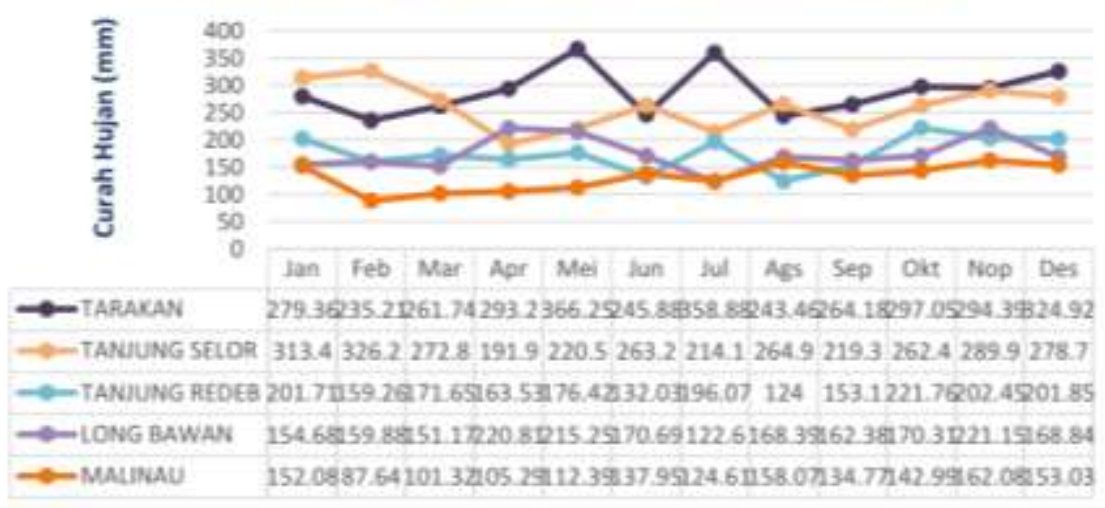

Gambar 2. Besaran Curah Hujan Rata-Rata

1. Pemetaan Curah Hujan Bulan Januari

Tabel 1. Data Pemetaan Input Nilai Curah Hujan Bulan Januari

\begin{tabular}{llcrr}
\hline \multirow{2}{*}{ No } & \multirow{2}{*}{ Nama Stasiun } & \multicolumn{2}{c}{ Koordinat UMT } & Curah Hujan \\
\cline { 3 - 5 } & & $\mathbf{X}$ & $\mathbf{Y}$ & $\mathbf{Z}$ \\
\hline 1 & Tanjung Harapan - Tanjung Selor & 541498 & 313787 & 313.43 \\
2 & Tuvai Semaring - Long Bawan & 354486 & 431089 & 154.68 \\
3 & Juwata - Tarakan & 563108 & 367715 & 279.36 \\
4 & Kalimarau - Tanjung Redeb & 548249 & 237413 & 201.71 \\
5 & R.A. Bessing - Malinau & 457612 & 395316 & 152.08 \\
\hline
\end{tabular}

Hasil dari proses interpolasi nilai curah hujan bulan Januari menggunakan metode Kriging di wilayah Kalimantan Utara dapat dilihat pada Gambar 3.

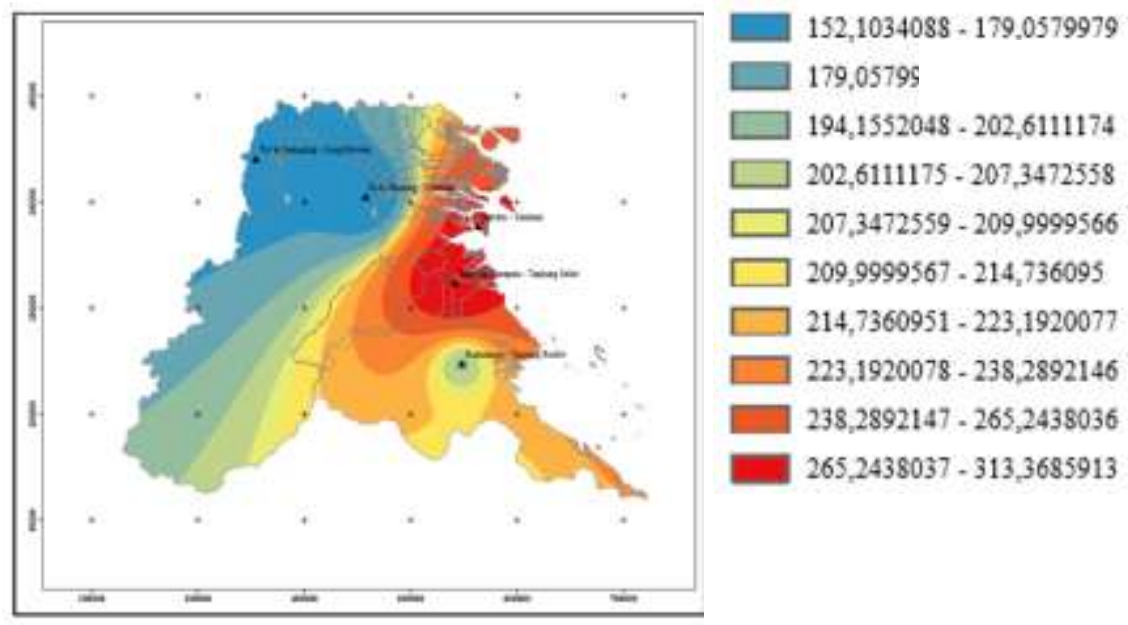

Gambar 3. Pemetaan Curah Hujan Bulan Januari

Dilihat dari hasil pemetaan curah hujan Bulan Januari, jarak titik koordinat yang berdekatan menghasilkan nilai curah hujan yang sama dan selanjutnya dengan titik koordinat yang berjauhan nilai curah hujan lebih variatif dengan tinggi curah hujan sesuai dengan data curah hujan bulanan yang ada. Nilai curah hujan tertinggi terdapat di wilayah Tanjung Selor dan Tarakan dengan curah 
hujan 265,24 mm sampai dengan 313,56 mm. Dan curah hujan terendah pada wilayah Long Bawan dan Malinau dengan nilai curah hujan 152,10 mm sampai dengan 179,05 mm.

2. Pemetaan Curah Hujan Bulan Februari

Tabel 2. Data Pemetaan Input Nilai Curah Hujan Bulan Februari

\begin{tabular}{clrrr}
\hline \multirow{2}{*}{ No } & \multicolumn{1}{|}{ Nama Stasiun } & \multicolumn{2}{c}{ Koordinat UMT } & \multicolumn{2}{c}{ Curah Hujan } \\
\cline { 3 - 5 } & & $\mathbf{X}$ & $\mathbf{Y}$ & $\mathbf{Z}$ \\
\hline 1 & Tanjung Harapan - Tanjung Selor & 541498 & 313787 & 326.24 \\
2 & Tuvai Semaring - Long Bawan & 354486 & 431089 & 159.88 \\
3 & Juwata - Tarakan & 563108 & 367715 & 235.21 \\
4 & Kalimarau - Tanjung Redeb & 548249 & 237413 & 159.26 \\
5 & R.A. Bessing - Malinau & 457612 & 395316 & 87.64 \\
\hline
\end{tabular}

Hasil dari proses interpolasi nilai curah hujan bulan Februari menggunakan metode Kriging di wilayah Kalimantan Utara dapat dilihat pada Gambar 4.

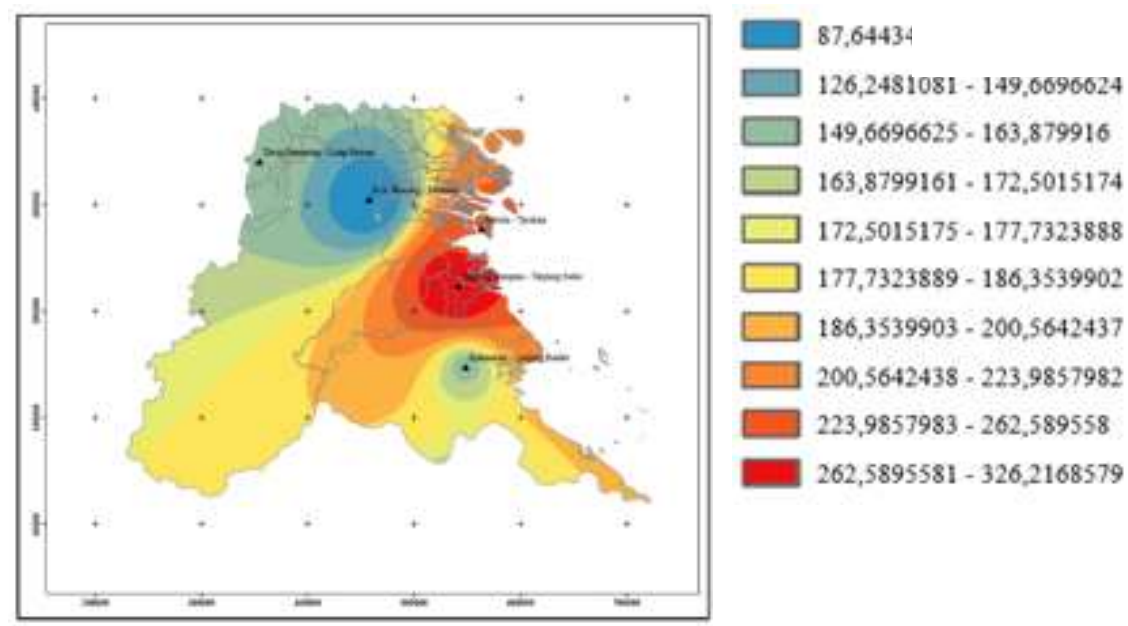

Gambar 4. Pemetaan Curah Hujan Bulan Februari

Dilihat dari hasil pemetaan curah hujan Bulan Februari, masing-masing titik koordinat menghasilkan nilai curah hujan yang sama sesuai dengan data dan selanjutnya dengan titik koordinat yang berjauhan menghasilkan nilai curah hujan lebih variatif. Nilai curah hujan tertinggi terdapat di wilayah Tanjung Selor dengan curah hujan 262,589 mm sampai dengan 326,217 mm. Dan curah hujan terendah pada wilayah Malinau dengan nilai curah hujan 87,649 mm sampai dengan 126,248 $\mathrm{mm}$.

3. Pemetaan Curah Hujan Bulan Maret

Tabel 3. Data Pemetaan Input Nilai Curah Hujan Bulan Maret

\begin{tabular}{|c|c|c|c|c|}
\hline \multirow{2}{*}{ No } & \multirow{2}{*}{ Nama Stasiun } & \multicolumn{2}{|c|}{ Koordinat UTM } & \multirow{2}{*}{$\begin{array}{c}\text { Curah Hujan } \\
\mathrm{Z}\end{array}$} \\
\hline & & $\mathbf{X}$ & $\mathbf{Y}$ & \\
\hline 1 & Tanjung Harapan - Tanjung Seloı & 541498 & 313787 & 272.80 \\
\hline 2 & Tuvai Semaring - Long Bawan & 354486 & 431089 & 151.17 \\
\hline 3 & Juwata - Tarakan & 563108 & 367715 & 261.74 \\
\hline 4 & Kalimarau - Tanjung Redeb & 548249 & 237413 & 171.65 \\
\hline 5 & R.A. Bes sing - Malinau & 457612 & 395316 & 101.32 \\
\hline
\end{tabular}


Hasil dari proses interpolasi nilai curah hujan bulan Maret menggunakan metode Kriging di wilayah Kalimantan Utara dapat dilihat pada Gambar 5.

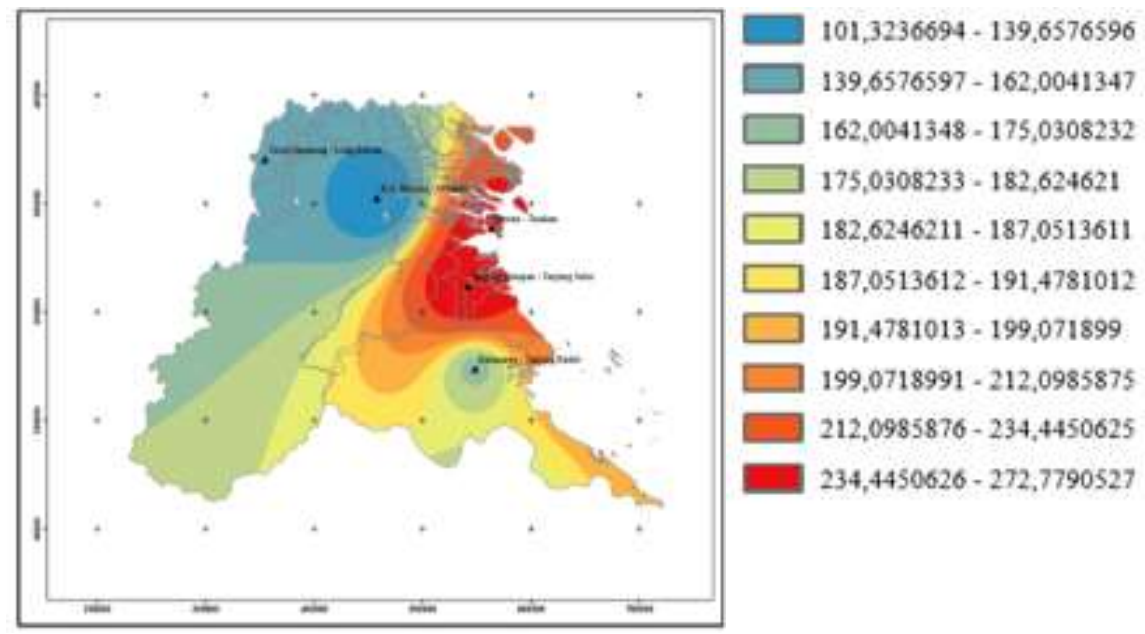

Gambar 5. Pemetaan Curah Hujan Bulan Maret

Dilihat dari hasil pemetaan curah hujan Bulan Maret, masing-masing titik koordinat menghasilkan nilai curah hujan yang sama sesuai dengan data dan selanjutnya dengan titik koordinat yang berjauhan menghasilkan nilai curah hujan lebih variatif. Nilai curah hujan tertinggi terdapat di wilayah Tanjung Selor dengan curah hujan 234,445 mm sampai dengan 272,779 mm. Dan curah hujan terendah pada wilayah Malinau dengan nilai curah hujan 101,323 mm sampai dengan $139,657 \mathrm{~mm}$.

4. Pemetaan Curah Hujan Bulan April

Tabel 4. Data Pemetaan Input Nilai Curah Hujan Bulan April

\begin{tabular}{|c|c|c|c|c|}
\hline \multirow{2}{*}{ No } & \multirow{2}{*}{ Nama Stasiun } & \multicolumn{2}{|c|}{ Koordinat UMT } & \multirow{2}{*}{$\begin{array}{c}\text { Curah Hujan } \\
\mathbf{Z} \\
\end{array}$} \\
\hline & & $\mathbf{X}$ & $\mathbf{Y}$ & \\
\hline 1 & Tanjung Harapan - Tanjung Selor & 541498 & 313787 & 191.95 \\
\hline 2 & Tuvai Semaring - Long Bawan & 354486 & 431089 & 220.81 \\
\hline 3 & Juwata - Tarakan & 563108 & 367715 & 293.20 \\
\hline 4 & Kalimarau - Tanjung Redeb & 548249 & 237413 & 163.53 \\
\hline 5 & R.A. Bessing - Malinau & 457612 & 395316 & 105.29 \\
\hline
\end{tabular}

Hasil dari proses interpolasi nilai curah hujan bulan April menggunakan metode Kriging di wilayah Kalimantan Utara dapat dilihat pada Gambar 6.

Dilihat dari hasil pemetaan curah hujan Bulan April, masing-masing titik koordinat menghasilkan nilai curah hujan yang sama sesuai dengan data dan selanjutnya dengan titik koordinat yang berjauhan menghasilkan nilai curah hujan lebih variatif. Nilai curah hujan tertinggi terdapat di wilayah Tarakan dengan curah hujan 243,636 mm sampai dengan 293,191 mm. Dan curah hujan terendah pada wilayah Malinau dengan nilai curah hujan 105,294 mm sampai dengan 154,85 mm. 


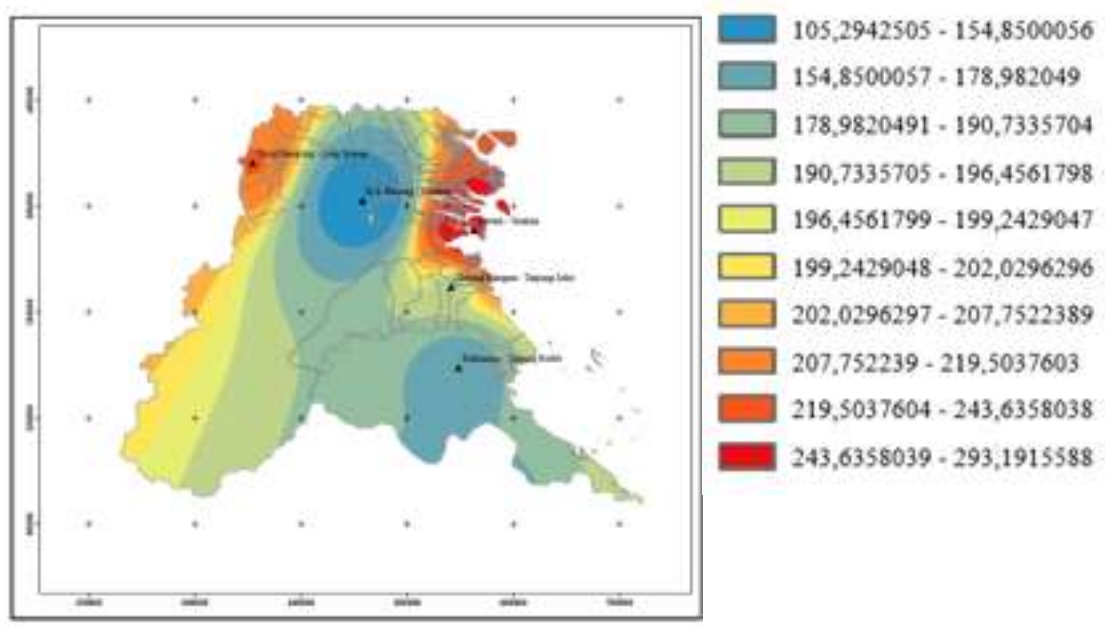

Gambar 6. Pemetaan Curah Hujan Bulan April

5. Pemetaan Curah Hujan Bulan Mei

Tabel 5. Data Pemetaan Input Nilai Curah Hujan Bulan Mei

\begin{tabular}{|c|c|c|c|c|}
\hline \multirow{2}{*}{ No } & \multirow{2}{*}{ Nama Stasiun } & \multicolumn{2}{|c|}{ Koordinat UMT } & \multirow{2}{*}{$\begin{array}{c}\text { Curah Hujan } \\
\mathbf{Z} \\
\end{array}$} \\
\hline & & $\mathbf{X}$ & $\mathbf{Y}$ & \\
\hline 1 & Tanjung Harapan - Tanjung Selor & 541498 & 313787 & 220.50 \\
\hline 2 & Tuvai Semaring - Long Bawan & 354486 & 431089 & 215.25 \\
\hline 3 & Juwata - Tarakan & 563108 & 367715 & 366.25 \\
\hline 4 & Kalimarau - Tanjung Redeb & 548249 & 237413 & 176.42 \\
\hline 5 & R.A. Bessing - Malinau & 457612 & 395316 & 112.39 \\
\hline
\end{tabular}

Hasil dari proses interpolasi nilai curah hujan bulan Mei menggunakan metode Kriging di wilayah Kalimantan Utara dapat dilihat pada Gambar 7.
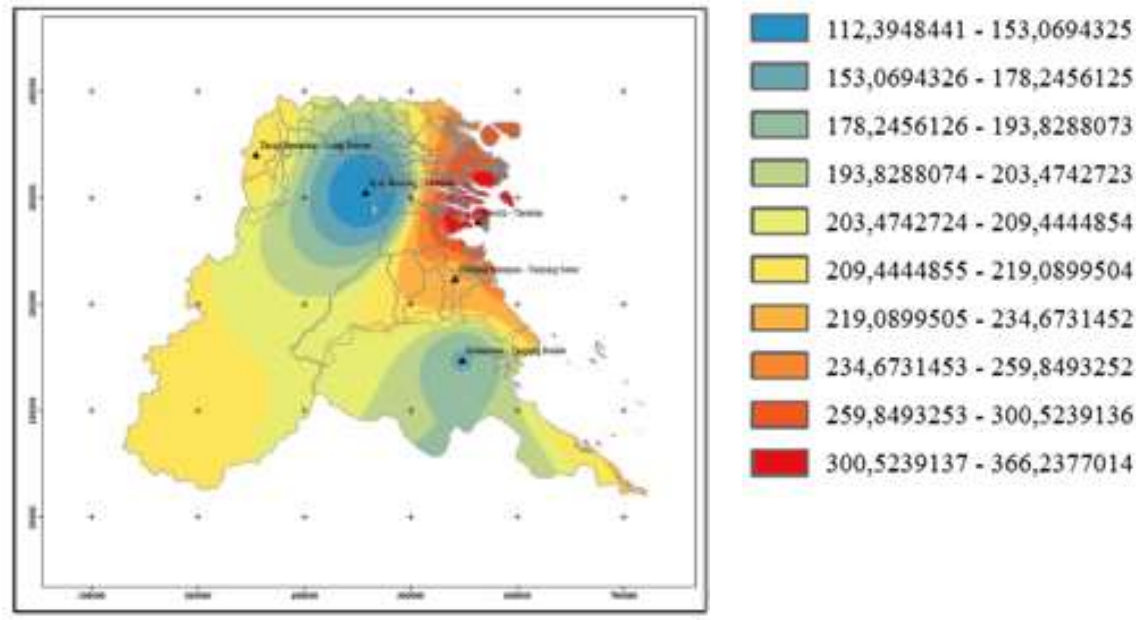

Gambar 7. Pemetaan Curah Hujan Bulan Mei

Dilihat dari hasil pemetaan curah hujan Bulan Mei, masing-masing titik koordinat menghasilkan nilai curah hujan yang sama sesuai dengan data dan selanjutnya dengan titik koordinat yang 
berjauhan menghasilkan nilai curah hujan lebih variatif. Nilai curah hujan tertinggi terdapat di wilayah Tarakan dengan curah hujan 300,524 mm sampai dengan 366,238 mm. Dan curah hujan terendah pada wilayah Malinau dengan nilai curah hujan 112,395 mm sampai dengan 153,069 mm.

6. Pemetaan Curah Hujan Bulan Juni

Tabel 6. Data Pemetaan Input Nilai Curah Hujan Bulan Juni

\begin{tabular}{clccr}
\hline \multirow{2}{*}{ No } & \multirow{2}{*}{ Nama Stasiun } & \multicolumn{2}{c}{ Koordinat UTM } & Curah Hujan \\
\cline { 3 - 5 } & & $\mathbf{X}$ & $\mathbf{Y}$ & $\mathbf{Z}$ \\
\hline 1 & Tanjung Harapan - Tanjung Selor & 541498 & 313787 & 263.28 \\
2 & Tuvai Semaring - Long Bawan & 354486 & 431089 & 170.69 \\
3 & Juwata - Tarakan & 563108 & 367715 & 245.88 \\
4 & Kalimarau - Tanjung Redeb & 548249 & 237413 & 132.03 \\
5 & R.A. Bessing - Malinau & 457612 & 395316 & 137.95 \\
\hline
\end{tabular}

Hasil dari proses interpolasi nilai curah hujan bulan Juni menggunakan metode Kriging di wilayah Kalimantan Utara dapat dilihat pada Gambar 8.

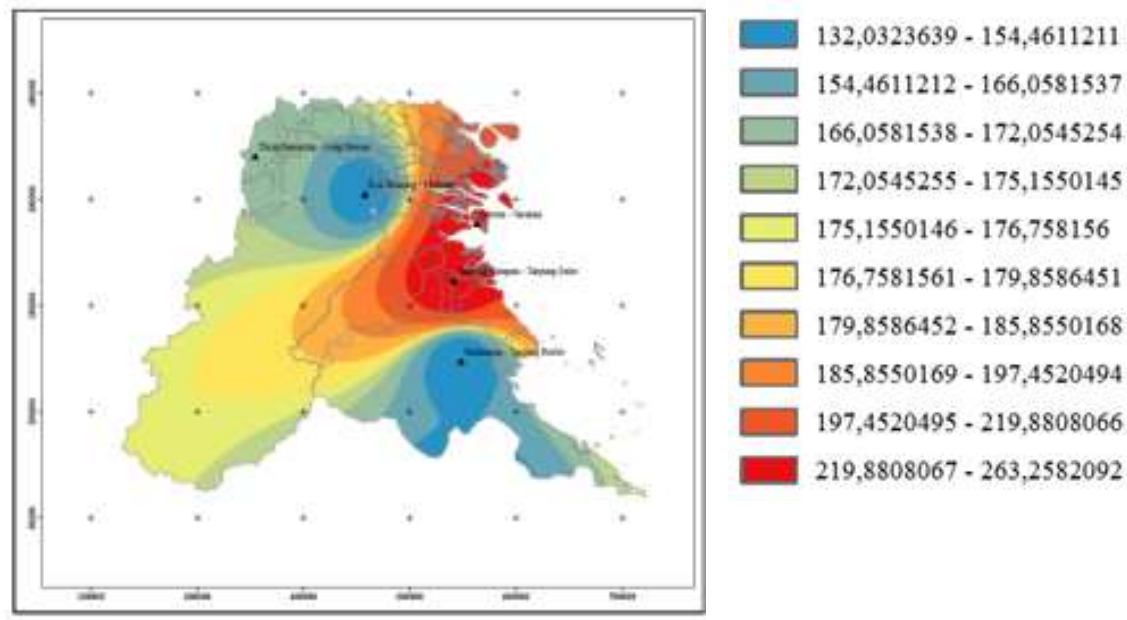

Gambar 8. Pemetaan Curah Hujan Bulan Juni

Dilihat dari hasil pemetaan curah hujan Bulan Juni, masing-masing titik koordinat menghasilkan nilai curah hujan yang sama sesuai dengan data dan selanjutnya dengan titik koordinat yang berjauhan menghasilkan nilai curah hujan lebih variatif. Nilai curah hujan tertinggi terdapat di wilayah Tanjung Selor dan Tarakan dengan curah hujan 219,88 mm sampai dengan 263,258 mm. Dan curah hujan terendah pada wilayah Malinau dan Tanjung Redeb dengan nilai curah hujan $132,032 \mathrm{~mm}$ sampai dengan $154,464 \mathrm{~mm}$.

\section{Pemetaan Curah Hujan Bulan Juli}

Dilihat dari hasil pemetaan curah hujan Bulan Juli, jarak titik koordinat yang berdekatan menghasilkan nilai curah hujan yang sama dan selanjutnya dengan titik koordinat yang berjauhan nilai curah hujan lebih variatif dengan tinggi curah hujan sesuai dengan data curah hujan bulanan yang ada. Nilai curah hujan tertinggi terdapat di wilayah Tarakan dengan curah hujan 299,054 mm sampai dengan 358,868 mm. Dan curah hujan terendah pada wilayah Long Bawan dan Malinau dengan nilai curah hujan 122,60 mm sampai dengan 144,182 mm. 
Tabel 7. Data Pemetaan Input Nilai Curah Hujan Bulan Juli

\begin{tabular}{clccc}
\hline \multirow{2}{*}{ No } & \multirow{2}{*}{ Nama Stasiun } & \multicolumn{2}{c}{ Koordinat UMT } & Curah Hujan \\
\cline { 3 - 5 } & & $\mathbf{X}$ & $\mathbf{Y}$ & $\mathbf{Z}$ \\
\hline 1 & Tanjung Harapan - Tanjung Selor & 541498 & 313787 & 214.10 \\
2 & Tuvai Semaring - Long Bawan & 354486 & 431089 & 122.60 \\
3 & Juwata - Tarakan & 563108 & 367715 & 358.88 \\
4 & Kalimarau - Tanjung Redeb & 548249 & 237413 & 196.07 \\
5 & R.A. Bessing - Malinau & 457612 & 395316 & 124.61 \\
\hline
\end{tabular}

Hasil dari proses interpolasi nilai curah hujan bulan Juli menggunakan metode Kriging di wilayah Kalimantan Utara dapat dilihat pada Gambar 9.
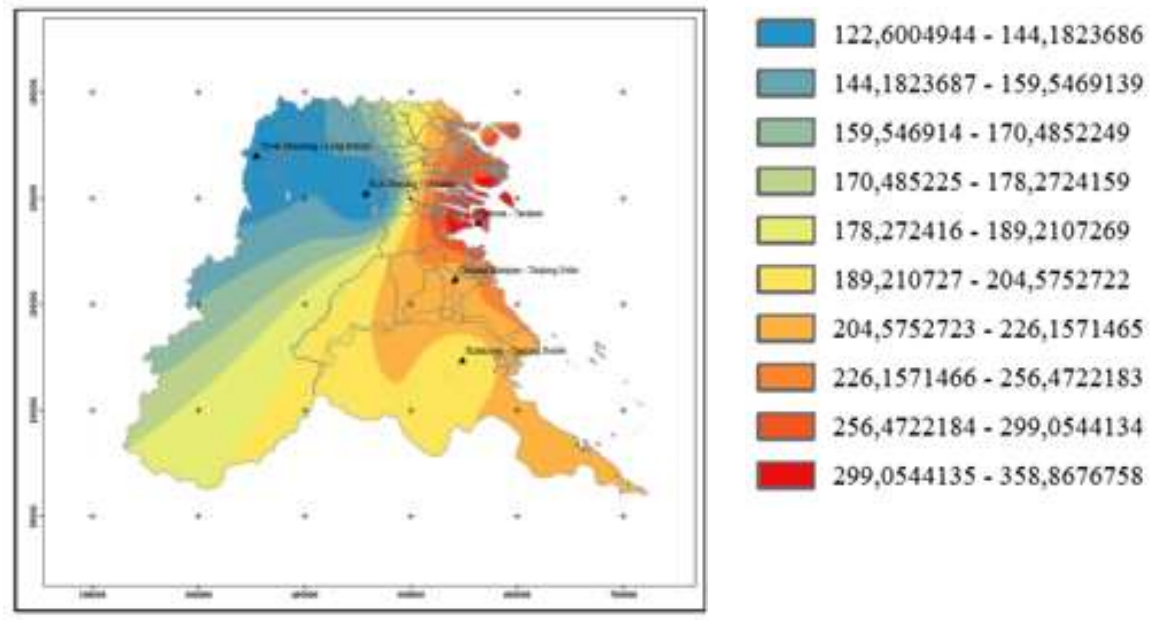

Gambar 9. Pemetaan Curah Hujan Bulan Juli

Dilihat dari hasil pemetaan curah hujan Bulan Juli, jarak titik koordinat yang berdekatan menghasilkan nilai curah hujan yang sama dan selanjutnya dengan titik koordinat yang berjauhan nilai curah hujan lebih variatif dengan tinggi curah hujan sesuai dengan data curah hujan bulanan yang ada. Nilai curah hujan tertinggi terdapat di wilayah Tarakan dengan curah hujan 299,054 mm sampai dengan 358,868 mm. Dan curah hujan terendah pada wilayah Long Bawan dan Malinau dengan nilai curah hujan 122,60 mm sampai dengan 144,182 mm.

8. Pemetaan Curah Hujan Bulan Agustus

Tabel 8. Data Pemetaan Input Nilai Curah Hujan Bulan Agustus

\begin{tabular}{clccc}
\hline \multirow{2}{*}{ No } & \multicolumn{1}{c}{ Nama Stasiun } & \multicolumn{2}{c}{ Koordinat UMT } & \multicolumn{2}{c}{ Curah Hujan } \\
\cline { 3 - 5 } 1 & Tanjung Harapan - Tanjung Selo & 541498 & 313787 & 214.10 \\
2 & Tuvai Semaring - Long Bawan & 354486 & 431089 & 122.60 \\
3 & Juwata - Tarakan & 563108 & 367715 & 358.88 \\
4 & Kalimarau - Tanjung Redeb & 548249 & 237413 & 196.07 \\
5 & R.A. Bessing - Malinau & 457612 & 395316 & 124.61 \\
\hline
\end{tabular}

Hasil dari proses interpolasi nilai curah hujan bulan Agustus menggunakan metode Kriging di wilayah Kalimantan Utara dapat dilihat pada Gambar 10. 


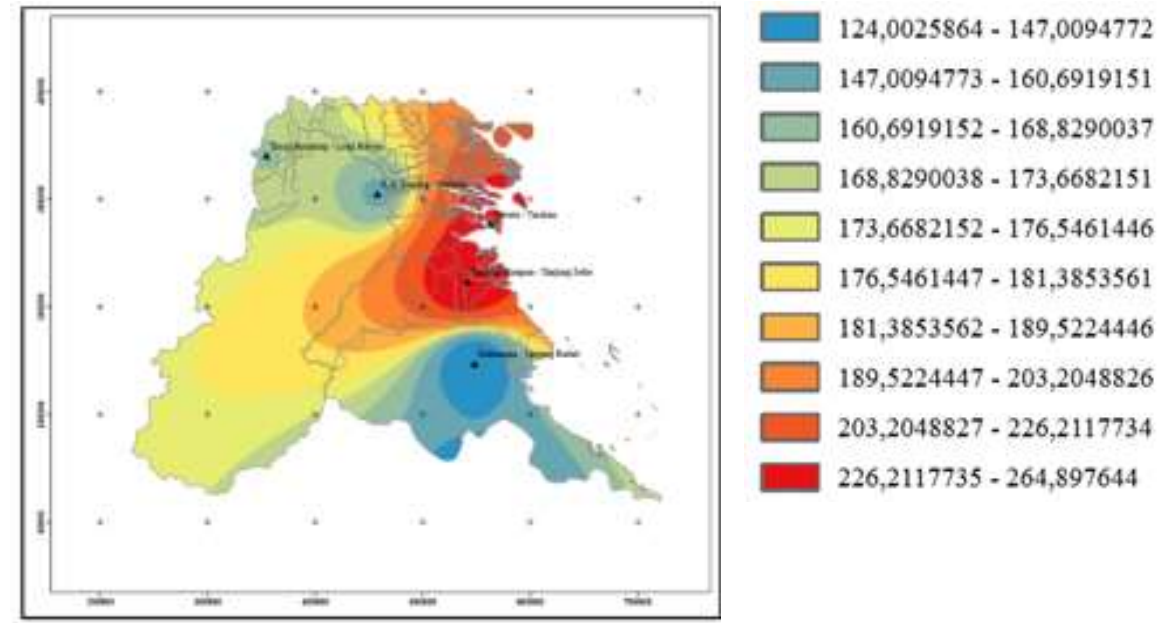

Gambar 10. Pemetaan Curah Hujan Bulan Agustus

Dilihat dari hasil pemetaan curah hujan Bulan Agustus, masing-masing titik koordinat menghasilkan nilai curah hujan yang sama sesuai dengan data dan selanjutnya dengan titik koordinat yang berjauhan menghasilkan nilai curah hujan lebih variatif. Nilai curah hujan tertinggi terdapat di wilayah Tanjung Selor dan Tarakan dengan curah hujan 226,211 mm sampai dengan 264,897 mm. Dan curah hujan terendah pada wilayah Tanjung Redeb dengan nilai curah hujan $124,002 \mathrm{~mm}$ sampai dengan $147,009 \mathrm{~mm}$.

9. Pemetaan Curah Hujan Bulan September

Tabel 9. Data Pemetaan Input Nilai Curah Hujan Bulan September

\begin{tabular}{|c|c|c|c|c|}
\hline \multirow{2}{*}{ No } & \multirow{2}{*}{ Nama Stasiun } & \multicolumn{2}{|c|}{ Koordinat UMT } & \multirow{2}{*}{$\begin{array}{c}\text { Curah Hujan } \\
\mathbf{Z} \\
\end{array}$} \\
\hline & & $\mathbf{X}$ & $\mathbf{Y}$ & \\
\hline 1 & Tanjung Harapan - Tanjung Selor & 541498 & 313787 & 219.32 \\
\hline 2 & Tuvai Semaring - Long Bawan & 354486 & 431089 & 162.38 \\
\hline 3 & Juwata - Tarakan & 563108 & 367715 & 264.18 \\
\hline 4 & Kalimarau - Tanjung Redeb & 548249 & 237413 & 153.10 \\
\hline 5 & R.A. Bessing - Malinau & 457612 & 395316 & 134.77 \\
\hline
\end{tabular}

Hasil dari proses interpolasi nilai curah hujan bulan September menggunakan metode Kriging di wilayah Kalimantan Utara dapat dilihat pada Gambar 11.
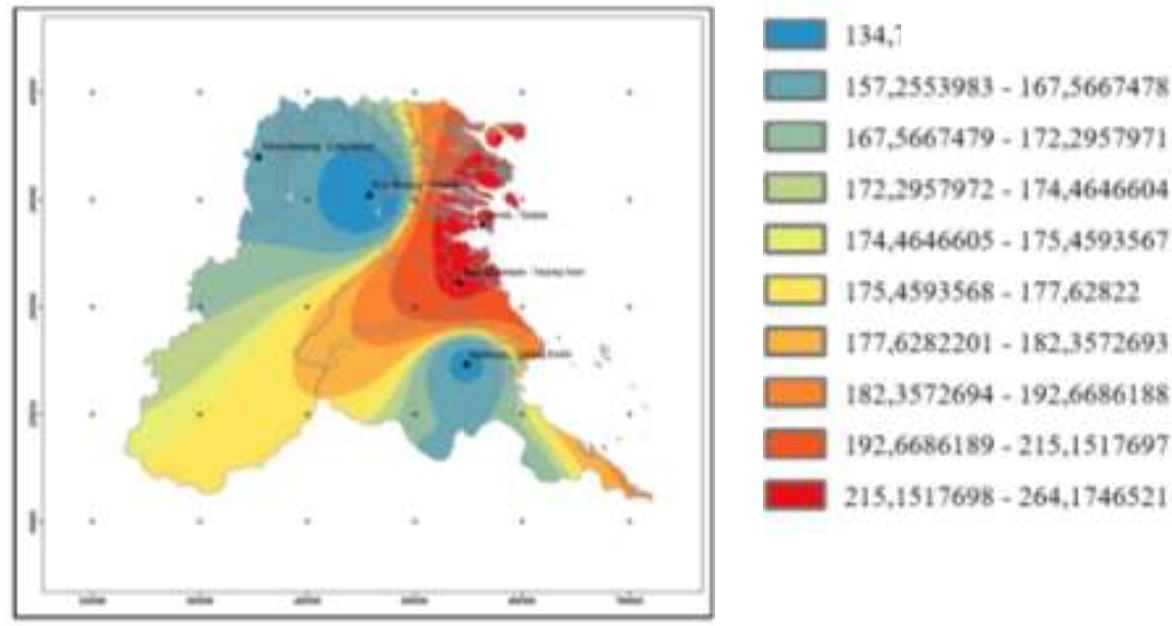

Gambar 11. Pemetaan Curah Hujan Bulan September 
Dilihat dari hasil pemetaan curah hujan Bulan September, masing-masing titik koordinat menghasilkan nilai curah hujan yang sama sesuai dengan data dan selanjutnya dengan titik koordinat yang berjauhan menghasilkan nilai curah hujan lebih variatif. Nilai curah hujan tertinggi terdapat di wilayah Tanjung Selor dan Tarakan dengan curah hujan 215,151 mm sampai dengan 264,175 mm. Dan curah hujan terendah pada wilayah Malinau dan Tanjung Redeb dengan nilai curah hujan 134,77 mm sampai dengan 157,255 mm.

10. Pemetaan Curah Hujan Bulan Oktober

Tabel 10. Data Pemetaan Input Nilai Curah Hujan Bulan Oktober

\begin{tabular}{llccc}
\hline \multirow{2}{*}{ No } & \multirow{2}{*}{ Nama Stasiun } & \multicolumn{2}{c}{ Koordinat UMT } & \multicolumn{2}{c}{ Curah Hujan } \\
\cline { 3 - 5 } & & $\mathbf{X}$ & $\mathbf{Y}$ & $\mathbf{Z}$ \\
\hline 1 & Tanjung Harapan - Tanjung Selor & 541498 & 313787 & 262.40 \\
2 & Tuvai Semaring - Long Bawan & 354486 & 431089 & 170.31 \\
3 & Juwata - Tarakan & 563108 & 367715 & 297.05 \\
4 & Kalimarau - Tanjung Redeb & 548249 & 237413 & 221.76 \\
5 & R.A. Bessing - Malinau & 457612 & 395316 & 142.99 \\
\hline
\end{tabular}

Hasil dari proses interpolasi nilai curah hujan bulan Oktober menggunakan metode Kriging di wilayah Kalimantan Utara dapat dilihat pada Gambar 12.

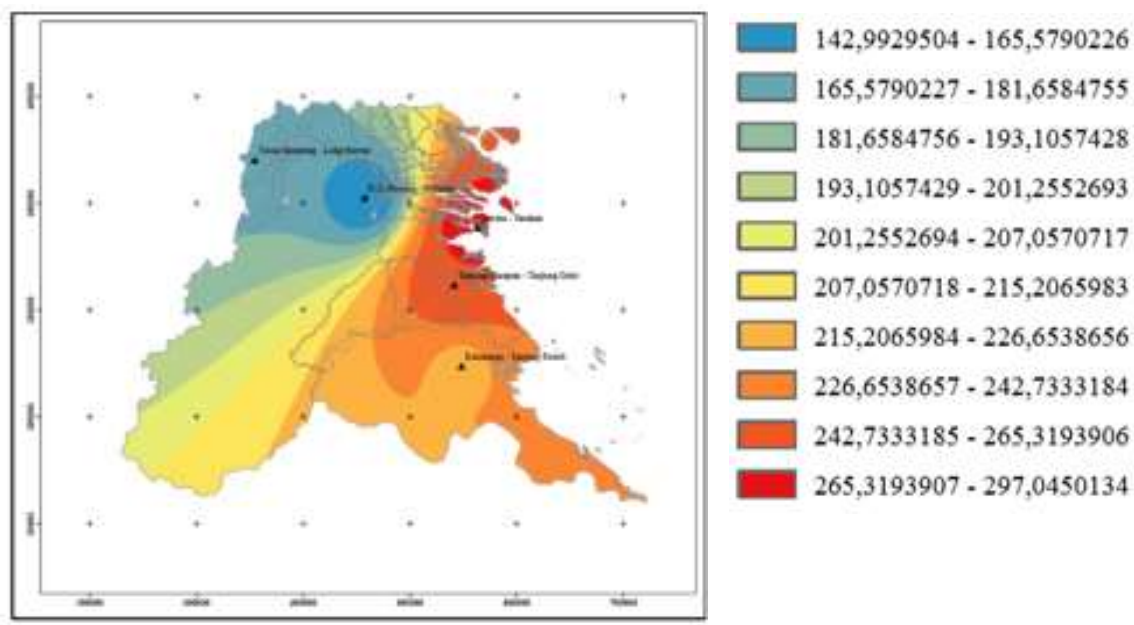

Gambar 12. Pemetaan Curah Hujan Bulan Oktober

Dilihat dari hasil pemetaan curah hujan Bulan Oktober, jarak titik koordinat yang berdekatan menghasilkan nilai curah hujan yang sama dan selanjutnya dengan titik koordinat yang berjauhan nilai curah hujan lebih variatif dengan tinggi curah hujan sesuai dengan data curah hujan bulanan yang ada. Nilai curah hujan tertinggi terdapat di wilayah Tarakan dengan curah hujan 265,319 mm sampai dengan 297,045 mm. Dan curah hujan terendah pada wilayah Malinau dengan nilai curah hujan 142,99 mm sampai dengan 165,579 $\mathrm{mm}$.

\section{Pemetaan Curah Hujan Bulan Nopember}

Dilihat dari hasil pemetaan curah hujan Bulan Nopember, masing-masing titik koordinat menghasilkan nilai curah hujan yang sama sesuai dengan data dan selanjutnya dengan titik koordinat yang berjauhan menghasilkan nilai curah hujan lebih variatif. Nilai curah hujan tertinggi terdapat di wilayah Tanjung Selor dan Tarakan dengan curah hujan 261,213 mm sampai dengan 
294,387 mm. Dan curah hujan terendah pada wilayah Malinau dengan nilai curah hujan 162,083 mm sampai dengan 195,256 mm.

Tabel 11. Data Pemetaan Input Nilai Curah Hujan Bulan Nopember

\begin{tabular}{llccc}
\hline \multirow{2}{*}{ No } & \multirow{2}{*}{ Nama Stasiun } & \multicolumn{2}{c}{ Koordinat UTM } & Curah Hujan \\
\cline { 3 - 5 } & & $\mathbf{X}$ & $\mathbf{Y}$ & $\mathbf{Z}$ \\
\hline 1 & Tanjung Harapan - Tanjung Selor & 541498 & 313787 & 289.92 \\
2 & Tuvai Semaring - Long Bawan & 354486 & 431089 & 221.15 \\
3 & Juwata - Tarakan & 563108 & 367715 & 294.39 \\
4 & Kalimarau - Tanjung Redeb & 548249 & 237413 & 202.45 \\
5 & R.A. Bessing - Malinau & 457612 & 395316 & 162.08 \\
\hline
\end{tabular}

Hasil dari proses interpolasi nilai curah hujan bulan Nopember menggunakan metode Kriging di wilayah Kalimantan Utara dapat dilihat pada Gambar 13.

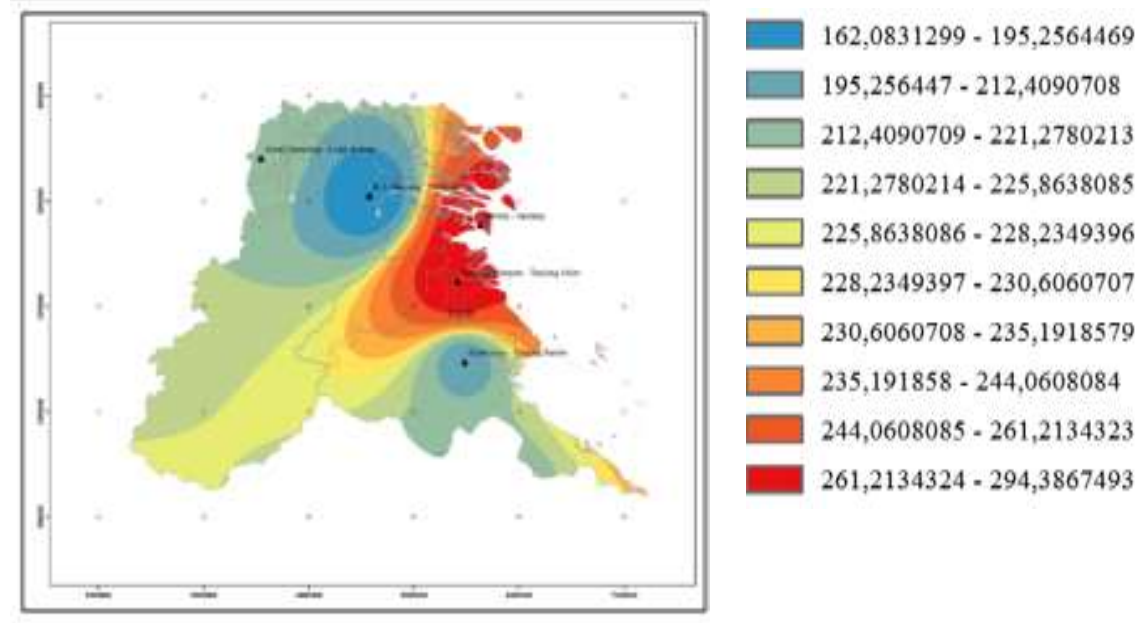

Gambar 13. Pemetaan Curah Hujan Bulan Nopember

12. Pemetaan Curah Hujan Bulan Desember

Tabel 12. Data Pemetaan Input Nilai Curah Hujan Bulan Desember

\begin{tabular}{llccc}
\hline \multirow{2}{*}{ No } & \multicolumn{1}{c}{ Nama Stasiun } & \multicolumn{2}{c}{ Koordinat UMT } & Curah Hujan \\
\cline { 3 - 5 } & & $\mathbf{X}$ & $\mathbf{Y}$ & $\mathbf{Z}$ \\
\hline 1 & Tanjung Harapan - Tanjung Selor & 541498 & 313787 & 278.73 \\
2 & Tuvai Semaring - Long Bawan & 354486 & 431089 & 168.84 \\
3 & Juwata - Tarakan & 563108 & 367715 & 324.92 \\
4 & Kalimarau - Tanjung Redeb & 548249 & 237413 & 201.85 \\
5 & R.A. Bessing - Malinau & 457612 & 395316 & 153.03 \\
\hline
\end{tabular}

Hasil dari proses interpolasi nilai curah hujan bulan Desember menggunakan metode Kriging di wilayah Kalimantan Utara dapat dilihat pada Gambar 14.

Dilihat dari hasil pemetaan curah hujan Bulan Desember, jarak titik koordinat yang berdekatan menghasilkan nilai curah hujan yang sama dan selanjutnya dengan titik koordinat yang berjauhan 
nilai curah hujan lebih variatif dengan tinggi curah hujan sesuai dengan data curah hujan bulanan yang ada. Nilai curah hujan tertinggi terdapat di wilayah Tarakan dan Tanjung Selor, dengan curah hujan 269,481 mm sampai dengan 324,513 mm. Dan curah hujan terendah pada wilayah Malinau dan Long Bawan dengan nilai curah hujan 153,032 mm sampai dengan 182,273 mm.

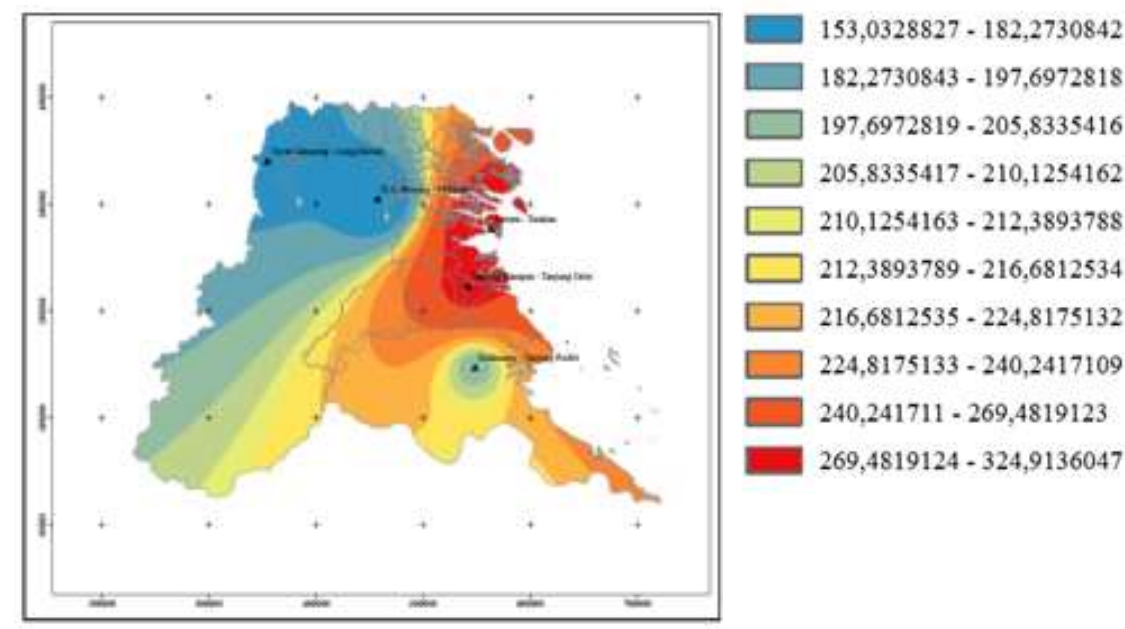

Gambar 14. Pemetaan Curah Hujan Bulan Desember

Pemetaan curah hujan bulanan yang telah dilakukan, secara visual terdapat dua tipe yang membedakan antara hasil pemetaan curah hujan tiap bulannya. Tipe tersebut menjelaskan tentang nilai curah hujan masing-masing wilayah dengan sebaran rentang nilai curah hujan yang kecil dan sebaran rentang nilai curah hujan yang besar pada masing-masing wilayah. Untuk rentang nilai curah hujan yang besar, sebaran curah hujan lebih variatif dibandingkan dengan rentang curah hujan yang kecil. Hal ini ditunjukan pada hasil pemetaan curah hujan bulan Januari, Juli, Oktober dan Desember rentang nilai curah hujan lebih besar dibandingkan pada bulan lainnya.

\section{Kesimpulan}

Dari hasil penelitian dengan judul Pemetaan Curah Hujan Dalam Upaya Mengurangi Resiko Bencana Hidrometeorologi Dengan Sistem Informasi Geografis (SIG) Untuk Wilayah Kalimantan Utara, beberapa kesimpulan yang dapat diambil adalah sebagai berikut :

1. Analisa curah hujan bulanan diambil dari 10 tahun data curah hujan untuk lima wilayah Kalimantan Utara. Hasil analisa curah hujan adalah rata-rata curah hujan bulanan, yaitu dari bulan Januari hingga bulan Desember.

2. Metode yang dapat digunakan untuk mengetahui nilai atau tinggi curah hujan bulanan untuk sebaran wilayah Kalimantan Utara adalah dengan metode Spatial Analyst Interpolation - Kriging. Hasil berupa peta curah hujan bulanan, yautu bulan Januari hingga bulan Desember.

3. Peta curah hujan bulanan menjadi sumber informasi nilai curah hujan masing-masing wilayah di Kalimantan Utara. Curah hujan maksimum terdapat di wilayah Tanjung Selor dan Tarakan pada bulan Januari 313,368 mm, bulan Mei 366,238 mm, bulan Juli 358,868 $\mathrm{mm}$ dan bulan Desember $324,513 \mathrm{~mm}$. Dengan tinggi rata-rata curah hujan diatas 300 $\mathrm{mm} / \mathrm{bulan}$.

4. Dapat disimpulkan bahan peta curah hujan bulanan untuk bulan Januari, Mei, Juli dan Desember menjadi parameter untuk mengantisipasi bencana hidrometeorologi, seperti banjir. 


\section{Ucapan Terima Kasih}

Penulis mengucapkan terima kasih kepada Direktorat Riset dan Pengabdian Masyarakat Direktorat Jenderal Penguatan Riset dan Pengembangan Kementerian Riset, Teknologi, dan Pendidikan Tinggi atas anggaran dana penelitian hibah RISTEKDIKTI sesuai surat perjanjian pelaksanaan penelitian nomor: SK/7/E/KPT/2019 tanggal 8 April 2019. Penulis juga mengucapkan terima kasih kepada semua pihak yang membantu dalam penelitian ini.

\section{Daftar Pustaka}

H. Suryatmojo, 2017. Konservasi DAS. Artikel Menara Ilmu Universitas Gadjah Mada, Yogyakarta

S. Adi 2013. Karakterisasi Bencana Banjir Bandang Di Indonesia, Jurnal Sains dan Teknologi Indonesia Vol 15, No 1, Jakarta

M. Gusti Hari, dkk, 2017. Pola Keterpaparan Banjir Tahun 2014, 2015, Dan 2016 Pada Wilayah Rentan Banjir Di Cekungan Bandung, Prosiding SNaPP2017 Sains dan Teknologi, Bandung.

Sugiyono, 2015. Metode Penelitian Kombinasi (Mix Methods). Bandung: Alfabeta.

Prahasta, Eddy, (2001), Konsep-Konsep Dasar Sistem Informasi Geografis, Informatika, Bandung 